\title{
THE USE OF CAD/CAM FOR TEXTILE DESIGNS AND FABRICS
}

\author{
Liliana Indrie ${ }^{1}$, Pablo Diaz-García ${ }^{2}$, Zlatina Kazlacheva ${ }^{3}$, \\ Ignacio Montava ${ }^{2}$ and Julieta llieva ${ }^{3}$ \\ ${ }^{1}$ Department of Textiles, Leather and Industrial Management, Faculty of Energy \\ Engineering and Industrial Management, University of Oradea, Romania \\ B. St. Delavrancea, no. 4, 410058 Oradea, Romania, e-mail: lindrie@uoradea.ro \\ ${ }^{2}$ Department of Textile Engineering, Escuela Politécnica Superior de Alcoy, \\ Universitat Politècnica de València, Spain \\ Plaza Ferrándiz y Carbonell s/n, 03801 Alcoy, Spain, e-mail: pdiazga@txp.upv.es \\ ${ }^{3}$ Faculty of Technics and Technologies of Yambol, Trakia University, Bulgaria \\ Graf Ignatiev 38, 8600 Yambol, Bulgaria, e-mail: zlatinka.kazlacheva@trakia-uni.bg
}

\begin{abstract}
The paper illustrates the role of CAD/CAM technology in developing virtual textile design on the computer screen. First, it was created the shape of the symbol "Flower of Life" from Sacred Geometry by using the CAD system ASCON Kompas for the design of shapes and the graphic software Adobe Photoshop for colour combinations. Then, we drew few graphic sketches of garments on which we applied the textile design "Flower of life". In order to obtain fabric-manufacturing orders, the image was processed with a specific design software for fabric: EAT DesignScope Victor. At last, we converted the design into a fabric by using the weaving machine Smit Textile GS900 Jacquard Loom.

Keywords: Flower of Life, ASCON Kompas, Adobe Photoshop, Smit Textile GS900 Jacquard Loom, textile designs, graphic sketches of garments, woven fabrics.
\end{abstract}

\section{INTRODUCTION}

Heavily used in textile industry as a designing medium as well as a tool for production, $\mathrm{CAD} / \mathrm{CAM}$ is an essential part of the design process, acting not only as a tool to create ideas, but also making the textile designs /fabric more attractive and competitive to meet the rapidly changing mood of the consumer for fashionable designs. The creative process is about creating a drawing of a garment [1-3] deriving versions of it, creating visualizations, developing, deriving and drawing up patterns, creating patterns, in order to enable the designer to visualize the design before committing to an actual fabric. The process can continue by generating realistic simulations of fabrics, which can be then transferred to a chosen loom for immediate weaving. Woven fabrics [4-6] are highly textured, thus the software gives the tools to set and display individually the yarn thickness, colour, and warp and weft density. The colours of patterns depend on the colour of the yarns, their combinations and the structures on the pattern surface. More recent developments of this technology have led to digital Jacquard processes, whereby designs created on computers are fed directly to looms.

\section{FROM TEXTILE DESINGNS TO FABRIC}

From design to processing, every step in producing the woven fabric is important. There were three steps required for us to follow, to build an output textile material.

The first step in our task was to generate the textile designs. The fabric we have chosen to

IRTIIE Vol. 7, No. 1, 2019 ISSN 1314-8788 (print), ISSN 1314-8796 (online), doi: 10.15547/artte.2019.01.003 


\section{IRTIIE}

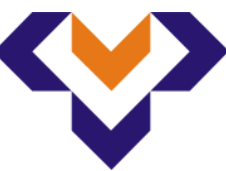

Ipplied Resseirlohes in Technics, Technologies and Eductition

Journal of the Faculty of Technics and Technologies, Trakia University https://sites.google.com/a/trakia-uni.bg/artte/

illustrate our final product is a jacquard weave. The jacquard usually combines two or more basic weaves, with different weaves used for the design and the background. We started by developing models with geometric structures, according to the market and lifestyle trends, and then we shaped the pattern by the means of the universal CAD system ASCON Kompas. Different textile designs were created based on the shape of "Flower of Life" symbol from Sacred Geometry. The figure was formed for displaying different pattern formations, adding dimension or colour reinforcement for enhancing the motif of Flower of Life.

By using the graphic software Adobe Photoshop new designs were created in different colour combinations in a short time and without any additional efforts.
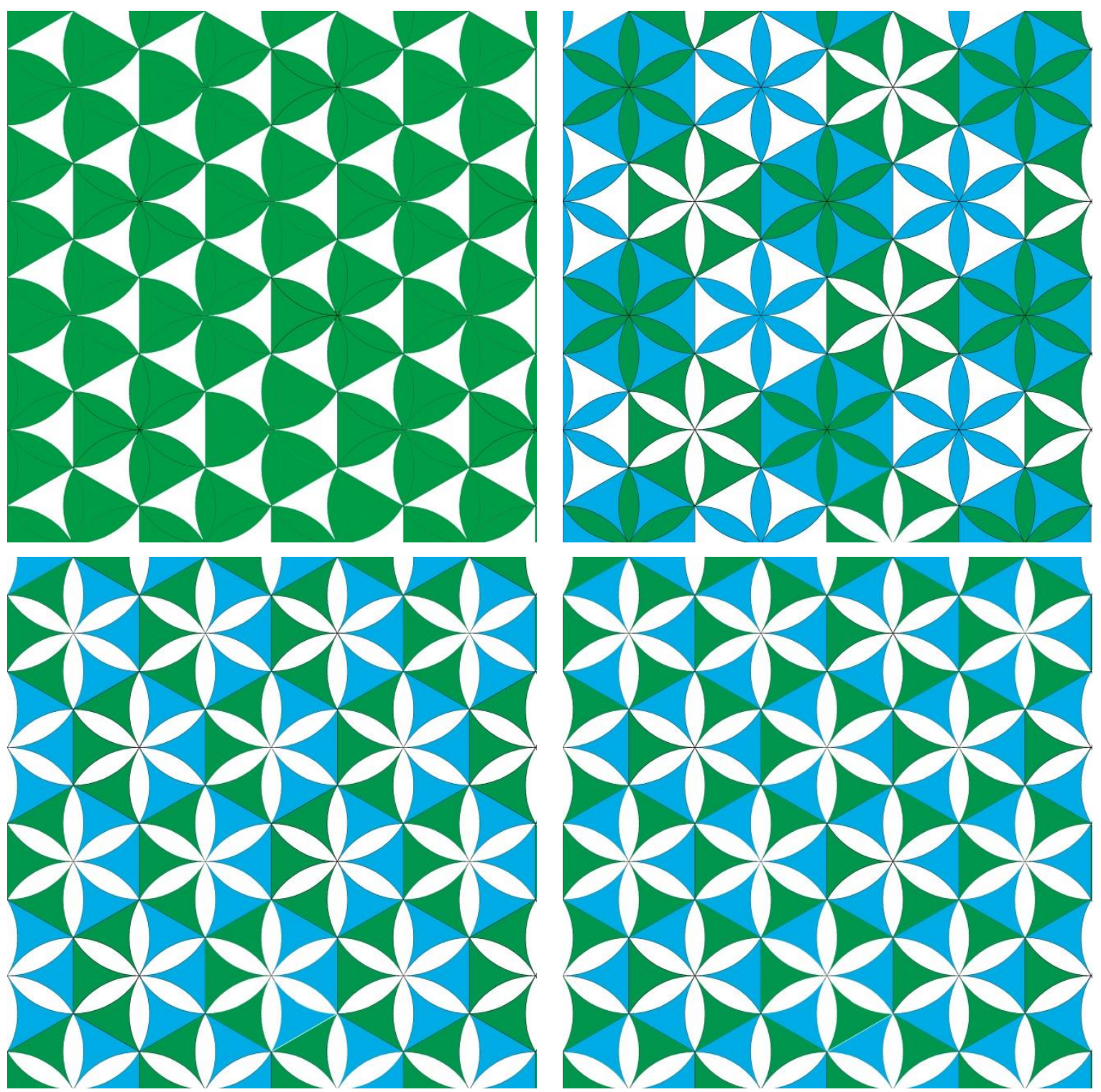

Figure 1. Textile designs based on Flower of Life

IRTIIE Vol. 7, No. 1, 2019 ISSN 1314-8788 (print), ISSN 1314-8796 (online), doi: 10.15547/artte.2019.01.003 


\section{IRTIE}

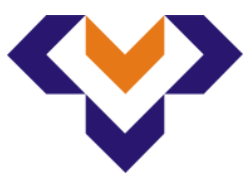

Ipplied Resseirlohes in Technics, Technologies and Eductition

Journal of the Faculty of Technics and Technologies, Trakia University https:///ites.google.com/a/trakia-uni.bg/artte/

Using the vector tools available in ASCON Kompas we designed the sketch for a dresses, as shown in figure 2 . The software offered us the possibility of increasing or decreasing the size of the design in the process of drafting the figure in the sketch.
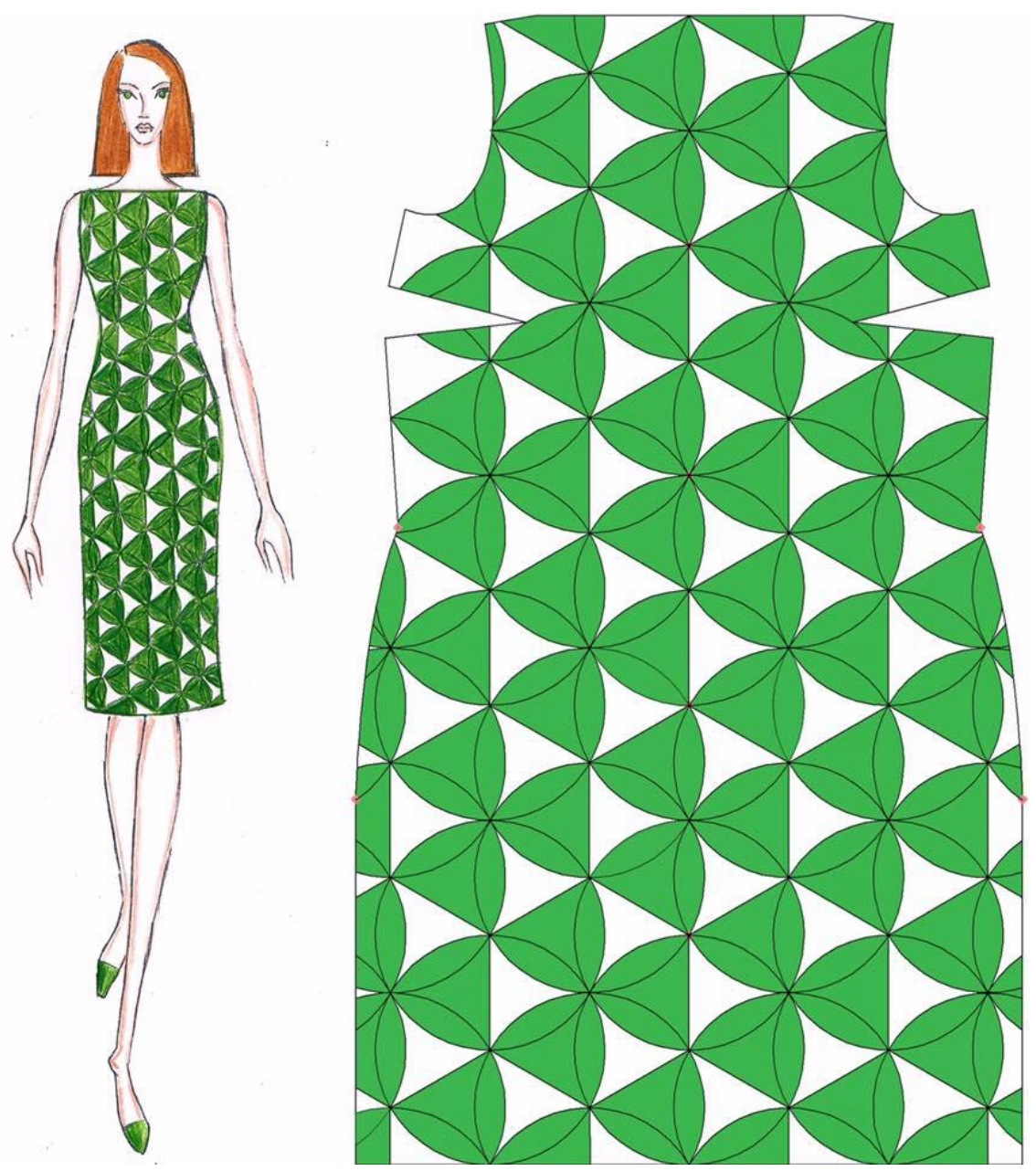

Figure 2. Dress sketch by ASCON Kompas

The second step was fabric designing, in which the image data was transformed into weaving information for fabric production. In order to obtain fabric-manufacturing orders, the image has been processed with EAT DesignScope victor. This software provides a variety of design tools (for preparing the base of the image, cleaning, retouching, drawing from the beginning, creating different rapports) that are supported by standardized colour databases and converts imported designs scanned or created by programs of conventional design into work orders for the jacquard machines of looms [7].

For every colour, it was possible to visualize automatically the result, offering us the possibility to rectify, make different combinations or proposals. Before being uploaded onto the platform and translated into a series of instructions for a Jacquard loom, the pattern was automatically reduced into a limited number of colours and into the correct resolution and transferred to SMIT Textile GS900 Jacquard Loom [8] for immediate weaving. 


\section{ARTTIE $Y$}

Ipplied Resseirlohes in Technics, Technologies and Eductition Journal of the Faculty of Technics and Technologies, Trakia University https://sites.google.com/a/trakia-uni.bg/artte/

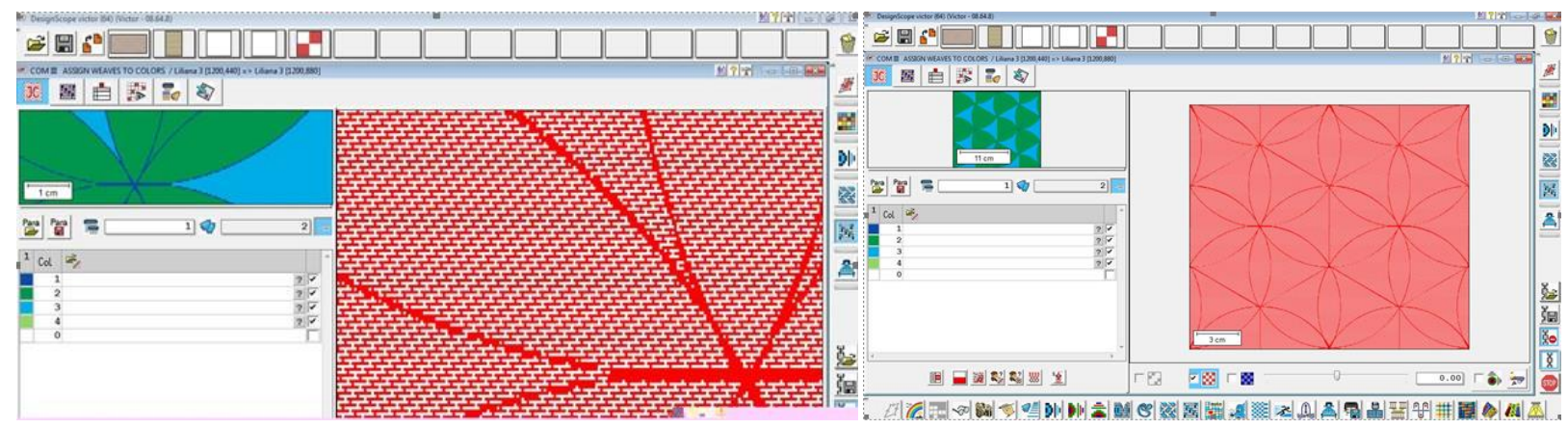

Figure 3. Processing the image by EAT DesignScope victor

The width of the loom is $190 \mathrm{~cm}$. The beam is composed by 9.600 threads, with a set of 60 picks/cm in the comb. The count of the warp thread used is polyester 17 TEX, in black colour. Two different yarns with the same count 23.5 TEX 2c, made of acrylic fibre in different colours (one green colour and the other one white colour) in relation 1:1, compose the weft. In order to obtain the complete design, the pattern repeats every $7 \mathrm{~cm}$.
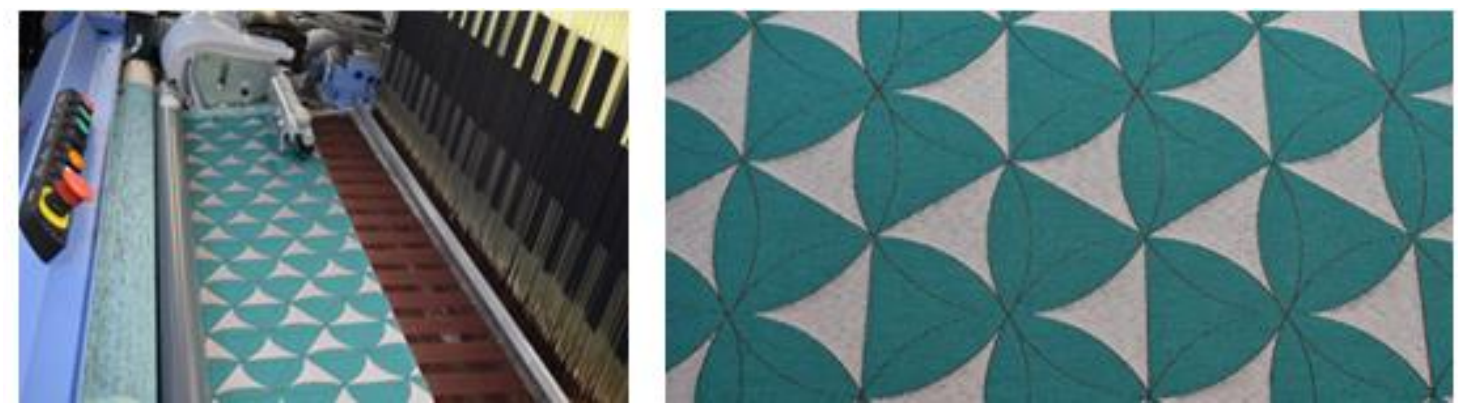

Figure 4. The fabric made by Smit Textile GS900 Jacquard Loom

\section{CONCLUSIONS}

CAD/CAM technology plays a vital role in textile designing as well as fabric manufacturing. Possessing flexible, dynamic and versatile techniques, the software offer the benefit of experimenting with a large number of colours, patterns, textures and sketch backgrounds for producing an animated design. In our approach, we show how CAD/CAM systems greatly simplifies the procedures involved both in the production and in processing of jacquard designs. We emphasize a short selection of the functions that CAD realizes to create designs colour reduction, elimination of spots out of its area, separation by colours, elimination of floats, and the possibility of visualizing different composition types of rapport in the same image. At the same time, CAM weaving system increased the pattern preparation for weaving as well as the possibility of making larger patterns or greater weave units.

\section{REFERENCES}

[1] Kazlacheva, Z., Fibonacci tilings in fashion design, Annals of the University of Oradea, Fascicle of Textiles-Leatherwork, Oradea, Vol. XVII, No. 1, 2016, pp. 77-82.

[2] Ilieva, J., Textile design on the base of the Golden geometry and Bulgarian national tradition, Annals of the University of Oradea, Fascicle of Textiles-Leatherwork, Oradea, Vol. XVII, No. 2, 2016, pp. 69-74.

IRTIIE Vol. 7, No. 1, 2019 ISSN 1314-8788 (print), ISSN 1314-8796 (online), doi: 10.15547/artte.2019.01.003 


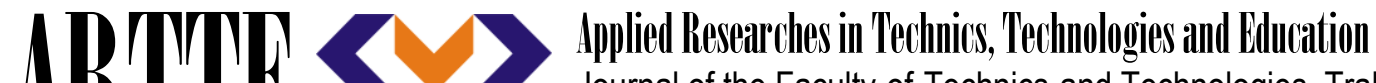 Journal of the Faculty of Technics and Technologies, Trakia University https://sites.google.com/a/trakia-uni.bg/artte/}

[3] Indrie L, Kazlacheva Z, Ilieva J., Gherghel S., Embroidery-from digital designing to fine art, Revista Industria Textilă, Vol. 68, No. 5, 2017, pp. 366-369, ISSN 1222-5347.

[4] Alderman S, Mastering Weave Structures; Transforming Ideas into Great Cloth, Loveland, CO: Interweave Press, 2004.

[5] Castelli, G., Maietta, S., Sigrisi, G., Slaviero, I., M., Reference books of textile technologies: weaving, Collections Edited by Fondazione ACIMIT, Italia, October 2000.

[6] Goerner, D., Woven structure and design, Wira Technology Group Ltd., 1986.

[7] The DesignScope Company EAT, [Online]. Available: http://www.designscopecompany.com/.

[8] Indrie L, Diaz-García P., Gherghel, S., Development of Jacquard woven fabrics for home decor, International Scientific Conference Contemporary Trends and Innovation in the txtile industry, 18 May 2018, Belgrade, Serbia, pp. 348-351. 